\title{
Private, Public and Foreign Investment Nexus in Pakistan: An Empirical Analysis of Crowding-In/Out Effects
}

Ahsan Abbas and Eatzaz Ahmed ${ }^{1}$

\begin{abstract}
This study empirically explores the relationship among private domestic, foreign direct and public investments for Pakistan economy using time series data from 1960 to 2015. Simultaneous equations and Vector Error Correction Model (VECM) frameworks are employed to examine the inter relationship among the three categories of investments. The study primarily works out crowding-in/out effect. Notably, the crowding-out effect is observed showing substitutability among the three types of investments. The study also finds that public, private domestic and foreign direct investments have strong positive impacts on economic growth. The findings suggest that better economic environment and favorable investment climate are pre-requisite to marginalize the crowding-out effect.
\end{abstract}

Keywords: Foreign Direct Investment, Public Investment, Private Domestic Investment, Crowding-in, Crowding-out, VECM, Economic Growth, Pakistan

\section{JEL Classification: C32, E22, 04}

\section{Introduction}

Effectiveness of fiscal policy rests on whether or not public investment crowds-out private investment. This traditional debate is now extended to include foreign investment in the analysis and to allow for crowding-in as well. A substantial amount of empirical research has emerged that explores the presence of substitutability (crowding-out) and complementarity (crowding-in) among private, public and foreign investments. The economic theory about existence of substitutability or complementarity. The direction of relationship may be in either way. For example, public investment in infrastructure may result in crowding-in effect through raising profitability that stimulates private investment (Barro, 1990). Complementarity effect mainly works through infrastructure such as provision of highways, transport, communication, education, health, and irrigation (Badawi, 2003; Greene and Villanueva, 1991; Aschauer, 1989) ${ }^{2}$. The empirical literature

\footnotetext{
${ }^{1}$ The authors are Senior Research Fellow at Centre of Excellence for CPEC, Islamabad and Professor on Memorial Chair State Bank of Pakistan, Department of Economics, Quaid-i-Azam University, Islamabad, respectively. Corresponding author's Email: ahsan.abbas@cpec-centre.pk ${ }^{2}$ Infrastructural development causes increase in the marginal product of private investment.
} 
states that in some economies state/government capital infusions are observed to be vital in alleviating supply bottlenecks, and increasing private sector development, thereby supporting crowding-in phenomenon (See Ermisch and Huff, 1999; Shafik, 1992; Lee, 1991; Wai and Wong, 1982).

Public investment can substitute or crowd out private investment through wastage of funds and diverting resources to projects that discourage or compete with private investment. Rising public expenditure leads to reduction in the availability of financial resources to private sector and upsurge in interest rate (Binter, 1977), increase future tax burden (Friedman, 1978), deficit-financing and resulting inflation creates uncertainty and further lowers private investment (Balcerzak and Rogalska, 2014; Blanchard and Fisher, 1989; Carlson and Spencer, 1975). ${ }^{3}$ Crowding-out effect is also described as Ricardian equivalence theorem (RET) occurred through higher deficits. Empirical literature has revealed the presence of this relationship (see Rossiter, 2002; Chibber and Wijnbergen, 1988). Another important linking variable in this context is the flow of foreign capital and similar effects may also be observed in terms of foreign direct investment (FDI). If FDI is friendly and stimulates private domestic investment, then it brings crowdingin effect. On the contrary, when FDI is seen as a competitor of private domestic investment then there will be a crowding-out of private investment that hampers the local entrepreneurship, especially the small and medium enterprises.

No single source of finance is enough for the sustained growth of an economy. Rather the combined capital market can contribute in a better way to provide the required investable funds for this purpose. The roles of public investment and foreign investment differ in terms of their nature. In this regard type of public investment (infrastructure or non-infrastructure) is quite important to describe the path of private, foreign, and total investment. Public investment displaces private investment by large margins in such economies where output is supply-constrained, and (private) consumption is quite stable (Badawi, 2003).

The link between public and private investment in the developing world is greater importance because government plays role not only in economic activities at large but also in the overall course of capital formation/investment. The use of scarce physical and financial resources by public sector diminishes the availability to the private enterprise and can cause crowding-out. The financing of public investment can be made through taxes or debt instruments. Additionally, the

\footnotetext{
${ }^{3}$ Also see Balcerzak and Rogalska (2014) and Carlson and Spencer (1975).
} 
production of competing marketable good by public sector also impedes the private investment.

Effects of FDI in terms of substitutability can be observed through cutthroat competition and limiting the resource accessibility or complementarity through knowledge spill over and technology knowhow. FDI is generally considered as a mode of finance that provides investible funds to a resource deficient small open economy/developing country and causes crowding-in effect, but this may not be the case for every country. The empirical relevance of the phenomena differs across countries and time.

Domestic investment can also play essential role in attracting foreign investment if it facilitates in providing the requisite infrastructure (Apergis et al., 2006). For a resource-deficient developing country like Pakistan foreign capital inflows are a great source of capital formation and the role of FDI is important in terms of expanding or narrowing the domestic economic opportunities, depending on the corresponding crowding-in/ out effect on domestic investment.

Thus, it is essential to figure out the relative contribution of the three categories of investments in aggregate output of a country, the channels of crowding-in/out effect, and the nexus between them. Economic activities in a country are multifaceted and interconnected. The economic system is, therefore, more a simultaneous game than sequential. In this paper, a simultaneous equations framework is considered to capture the relationship between economic growth and foreign and domestic (public and private) investment through channels effects of infrastructure development and cost of capital/investment.

Pakistan attracts some FDI inflow, but it lacks target orientation. Large government size and state intervention in economic activities affect not only the overall investment climate but also economic development of the country. It necessitates exploring the substitutability and/or complementarity among private, public and foreign investments in order to assess their relative contributions to the overall investment activity and economic growth. The beneficial or detrimental role of one type of investment (FDI) over the other (domestic investment) cannot be realized without knowing the notion(s) of crowding-in/out.

The study employs VECM model on the annual data for the period 19602016 to examine the long-run relationship and analyse the short-run dynamics between the variables under consideration.

The study is organized as follows. Literature review is presented in the section 2, while theoretical background of the model is explained in the section 3 . 
The discussion on data and estimation technique is provided in the section 4 . The analysis of the findings is presented in section 5, and the paper is concluded in section 6 .

\section{Literature Review}

A large number of studies have analyzed the behavior of public, private and foreign investments using both the single equation and multiple equation frameworks such as simultaneous equations and VAR models. However, findings of these studies vary considerably according to the theoretical assumptions, empirical models chosen, estimation techniques adopted, set of countries and the time span used for analysis. A brief description of the existing literature on the issue under consideration is as follows.

Rama (1993) discusses the issue of substitutability and complementary between public and private investments by examining eleven papers. The survey indicates that seven studies have found that private investment is complementary to public investment. ${ }^{4}$ The studies observe the crowding-in effect because a rise in public investment raises the rate of return on private investment (Ang, 2009; Aschauer, 1989). A number of other studies have also found that private investment increases when government makes investment in infrastructure and support the complementarity hypothesis ${ }^{5}$. In this regard, Looney (1997) concludes that in case of Pakistan private sector investment has been stimulated by selective types of government investment such as infrastructure. However, other than infrastructural activities, public sector competes with private sector and crowds-out private investment (Rashid, 2006; Sakr, 19936\% Blejer and Khan, 1984).

Inverse relationship, i.e., substitutability between public and private investment where former displaces or crowds out the latter, are observed by Ajaz and Nazima (2012), Ghani and Din (2006), Atukeren (2005), Voss (2002) and Balassa (1988). However, Gjini and Kukeli (2012), and Erden and Holcombe (2005) reveal the presence of crowding-out effect or substituting role in the developed economies but complementary role (crowding-in) in the developing countries.

\footnotetext{
${ }^{4}$ Oshikoya (1994), Ramirez (1994), Cardoso (1993), Bleaney and Greenaway (1993) and Shafik (1992) show similar results.

${ }^{5}$ Public capital stock crowds-in private capital through increasing the return to private capital.

${ }^{6}$ Sakr (1993) finds that GDP growth and public investment have significantly affected private investment in Pakistan from 1973-74 to 1991-92.
} 
A number of studies also have analyzed foreign and domestic investments nexus and explored the presence of substitutability and complementarity. Additionally, the role of foreign capital inflow in overall investment and economic progress of the recipient country is also examined.

De Soysa and Oneal (1999), Borensztein et al. (1998), Noorzoy (1979), and Van Loo (1977) observe the complementarity/crowding-in effect and find that FDI boosts domestic capital formation/investment. Ndikumana and Verick (2008) explore the link between FDI and private (domestic) investment and find the crowding-in effect. The study concludes that FDI positively influences domestic investment while improved domestic economic activities/conditions help to effectively drive the FDI. Tang et al. (2008) show that FDI not only boosts the domestic investment but also helps the economy to grow faster. Recently, Kamaly (2014) states that in most of the cases FDI positively and significantly affect domestic investment but the overall effect of FDI is economy specific.

On the contrary, Acar et al. (2012), Eregha (2012), De Backer and Sleuwaegen (2003) and Noorzoy (1980) find that there is substitutability or crowding-out effect of foreign investment on domestic investment. The analyses observe that the time span, i.e. long-run or short-run, also matters in investment behaviors. Titarenko (2006) explores the nature of FDI in Latvia and shows the presence of long-run crowding-out effect of FDI. ${ }^{7}$ But relatively short period of just 10 years can give misleading results. Hanif and Jalaluddin (2013) find that the FDI crowds out domestic investment in the short-run. Ugwuegbe et al. (2014) and Qi (2007) discover long-term dual causality between domestic and foreign investments.

For an analysis for various regions, Apergis et al. (2006) conclude that FDI crowds-out domestic investment for American and European economies but it has crowding- in effect for Asia and Africa. Agosin and Mayer (2000) finds a significant crowding-out effect for the Latin American economies but strong and relatively weak crowding-in effect for Asia and Africa, respectively. It is concluded that the effects of FDI on domestic investment are not always favorable. Earlier, Agosin and Machado (2005) and Kim and Seo (2003) shows that domestic investment is unresponsive to FDI. However, the crowding-out effect has also been observed for specific regions and several sub-periods. Adams (2009) states statistically significant and negative association between domestic investment and FDI. Further FDI has positive impact on the growth of the economy rather than on

${ }^{7}$ Also see Lipsey (2000) and Fry (1997). 
the accumulation of domestic capital. Sunny and Sawant (2012) find the crowdingout phenomenon for the case of China but crowding-in effect for India.

To explore the distinct cause and effect relationship some researches have analyzed the simultaneous relationship among the public, private domestic and foreign investments. Ang (2009) states both FDI and public investment crowd in private domestic investment ${ }^{8}$. However, private domestic investment is less influenced by public investment than FDI. On the contrary, Saglam and Yalta (2011) argue in the favor of no link among the three types of investments. The study finds insignificant involvement of foreign investment in overall investment activity in the case of Turkey, pointing out that competing relationship of foreign investment with the domestic one reduces the role of foreign investment role in economic growth and it poses challenge to reap the benefits from FDI. Amassoma and Ogbuagu (2014) reveal private investment and public investment shocks have respectively significant negative and positive influence on FDI. On the other hand, a shock in FDI positively and significantly affects the public investment and private domestic investment. The influence of public investment shock on the private investment suggests the crowding-in effect while the shock in private investment causes the public investment negatively. For Pakistan, Ali et al. (2015) reveal that the FDI significantly crowds in while the public investment crowds out the private investment.

The literature has also sought the issues of complementary and substitutability between domestic and foreign investments as well as the nexus between investment and economic growth. For example, Ford et al. (2010) show that in Chinese economy FDI is not significantly causing the total output i.e. GDP in the short-run. However, domestic investment rises with the level of FDI and domestic saving while economic growth accelerates FDI but the public spending on the infrastructure and monetary policy instruments decelerate FDI. Lean and Tan (2011) demonstrate that FDI positively impacts the economic growth whereas domestic investment causes the growth negatively. Further the findings support the crowding-in effect of FDI on domestic investment. The analysis also establishes the long-run equilibrium relationship (co-integration) among FDI, domestic investment and economic growth. Both economic growth and domestic investment (in the short-run) attract the FDI. However, the nature of relationships among the

\footnotetext{
8 The similar type of analyses has been carried out by Agosin and Machado (2005) for Asia, Bosworth and Collins (1999) for the panel of developing countries, Sun (1998) in case of China and Noorzoy (1979) and Van Loo (1977) for Canada.
} 
four variables varies considerably across various studies (for example see Lean and Tan, 2011; Ford et al., 2010).

The literature has also explored the role of investment in promoting economic growth. Badawi (2003) finds that both public and private investments stimulate economic growth. However, private investment contributes more in economic growth than the public investment. It narrows the favorable positive effects of public investment exerted on growth due to crowding-out and making private sector capital undertakings risky endeavor. Naqvi (2002) reveals that like accelerator-based models economic growth motivates both public and private investments.

Literature proposes the role of improved infrastructure as one of key policy intervention to enhance FDI as well overall investment in an economy (Ugwuegbe et al., 2014; Azam and Lukman, 20109; Masuku and Dlamini, 2009; Nasser, 2007). Notably, FDI is mainly determined by domestic investment (see Azam and Lukman; 2010)

In a study on the economic growth and investment nexus Carkovic and Levine (2005) reveal that foreign investment does not have independent robust impact on growth for the panel of countries. Alfaro et al. (2007) identify the direct link between FDI and economic growth i.e. higher levels of foreign investment lead to higher growth rates. However, development of financial market determines the intensity of the increase in growth rates due to FDI. The study also reveals that where multinational organizations are substitutes rather than compliments to domestic firms the output growth rates are relatively higher.

Chaudhry et al. (2013) examine the nexus between FDI and economic growth through ARDL approach. The analysis identifies that FDI, gross fixed capita formation and general government investment contribute in China's growth. The study proposes that China should focus on FDI enhancement to increase the economic growth. Olusanya (2013) focuses on the impact of good economic conditions for attracting FDI in Nigeria. Granger causality is used for the data set of 1970-2010. The findings reveal the causality between economic growth and FDI for pre-deregulation era but not for post-deregulation era. The FDI inflows are shown to be driven by economic growth. Naz et al. (2015) find a robust direct relationship between economic growth and FDI in case of Pakistan. Hanif and Jalaluddin (2013) maintain that domestic, foreign investment and development have long-run equilibrium relationship.

\footnotetext{
${ }^{9}$ The analysis reveals that FDI is mainly determined by domestic investment.
} 


\section{Theoretical Framework}

Investment, the volatile component of aggregate expenditure, is essentially determined by output or output growth (the accelerator principle), costs of investment (neoclassical approach ${ }^{10}$ ), expectations and business confidence ${ }^{11}$. Moreover, interdependence among various types of investments i.e. domestic, foreign and public is another important area of interest.

The public investment (in infrastructure) raises the rate of return of private investment, enhances the productivity of capital, increases the availability of resources and reduces the cost of doing business hence stimulates private investment (Ang, 2009). Similarly, the positive and encouraging impact of FDI on domestic investment works through provision of novel investment opportunities in terms of accessibility to technology and equipment, imitation of new technology at local level, possible joint ventures of domestic firms with foreign firms and introduction of new industries (see Ang, 2009). ${ }^{12}$ Increase in public or foreign investment, therefore, sets forth capital gain and raises the private investment. Similarly, private investment activity may also cause the other two categories of investments through positive investment climate in an economy. On the other hand, it may also happen that public or foreign investment displaces or substitutes private (domestic) investment.

In general, crowding out situation is stated as 'economic effects of expansionary fiscal actions' (Carlson and Spencer, 1975). The financing of government/public expenditures through issuance of debt or taxes, increases the interest rate that hampers the economic activity of private sector and crowds it out. ${ }^{13}$ Additionally, the lessening availability of financial and real resources to private sector utilized by (competing) public or foreign sector dampens the private (domestic) investment and, hence, crowds it out. Similarly, the increased

\footnotetext{
10 The cost of capital includes (change in) price of capital $(\Delta P k)$, interest rate $(r)$, depreciation (of capital) $(\delta)$, and taxes $(\tau)$. However, nominal interest rate $(i)$ minus expected inflation $\left(\pi^{e}\right)$ i.e. real interest rate $(r)$ is mostly used, in the empirical studies, as indicator of cost of capital.

11 This phenomenon indicates the inertia and sluggishness in macroeconomic variables such as investment.

${ }^{12}$ FDI begets both direct and indirect benefits not only to local or domestic investors but also to the host/recipient economy (Naz et al., 2015; Hanif and Jalaluddin, 2013).

13 The crowding-out effect may be zero, complete or partial depending on the given conditions and cases like Classical, Keynes, Knight, Ultrarational, Friedman (for details see Balcerzak and Rogalska, 2014; Carlson and Spencer, 1975). Carlson and Spencer (1975) have also analyzed the crowding-out effect in both real \& nominal terms.
} 
production of investment goods in the public sector, which compete with the products of private sector, leads to the crowding-out effect (Ang, 2009).

FDI may discourage or negatively impact the domestic investment activity when the foreign firms contest with local firms to grab the local limited resources, especially human and physical capital (Ang, 2009; Jansen, 1995). In the presence of advantage to foreign companies in terms of technological and managerial competencies as well as fiscal and commercial incentives offered to attract foreign investors, FDI crowds out the domestic (private) investment through disruption of (backward) linkages in local manufacturing in terms of import substitution for local goods (see Hanif and Jalaluddin, 2013; Noorzoy, 1979).

The other key determining factors of the three types of investment considered in this paper are cost of capital (real interest rate), and physical infrastructure (road density). The theory indicates positive or direct relationship between investment and GDP growth rate i.e. accelerator principle. However, there may exist two-way causal relationship between the two variables. Interest rate effects investment because businesses will be willing to borrow more funds to finance their investments when interest rate is less than the expected profitability of investment. Conventionally, the real interest rate deters investment. The crowding-out effect is channelized through rising interest rates. The physical infrastructure i.e., provision of highways, transport, and communication etc., is used to explain whether or not the resulting decrease in transportation and transaction cost raises the level of investment.

\section{Data and Model}

\subsection{The Description of Variables in the System}

In the light of above discussion, the focused variables considered in this paper are foreign direct investment (FDI $)^{14}$, private domestic investment (PDI) ${ }^{15}$, public investment (PUB) and gross domestic product (GDP) all taken at constant 200-01 prices. The control variables included in the analysis are real interest rate

\footnotetext{
14 The study uses private investment (gross fixed capital formation) (price) deflator, the ratio between nominal (private) investment and real (private) investment, to convert FDI in real terms. Ang (2009) has used gross fixed capital formation (investment) deflator to express all the investment series i.e. PDI, PUB, and FDI in real terms. This study has, however, used public investment deflator to express PUB in real terms.

${ }^{15} \mathrm{PDI}$ is constructed by subtracting (real) FDI from (real) private gross fixed capital formation i.e. private (fixed) investment (see Ang, 2009). Likewise, FDI, PDI is converted to real terms by dividing with private investment price deflator. Amassoma and Ogbuagu (2014) and Saglam and Yalta (2011) have also used PDI in their studies.
} 
and physical infrastructure. The real interest rate (Int) is constructed as the weighted average of three interest rates i.e. call money rate, discount rate and government bond yield rate (see Ahmad and Qayyum, 2009; Ahmad et al., 2008). After taking average, it is converted in real terms by subtracting GDP deflator inflation rate from the average. The physical infrastructure (PI) is proxied by the road density [ratio of the country's total road network's length in kilometers to the country's total (land) area or KM of road per sq. K.M of land area (total length of road/total area)]. Due to the presence of very strong inherent trend, the variable is de-trended.

The data have been collected from Handbook of Statistics on Pakistan Economy 2015, Pakistan Economic Survey and International Financial Statistics (IFS).

\subsection{The Econometric Model}

The economic growth, foreign direct, private domestic and public investments are interdependent on each other. Economic growth determines the private investment (accelerator effect) and public investment (Wagner's law), which in turn results in rise in demand for infrastructure, hence public investment (in infrastructural development) (Välilä and Mehrotra, 2005; Sturm, 2001). Moreover, economic growth is not only determined by public, foreign and domestic private investments but also by the interest rate and infrastructure. The impact of real interest rate and infrastructure on the aforementioned variables is, therefore, determined in the analysis. ${ }^{16}$ Finally various types of investments can also affect one another. This leads to a simultaneous equation system based on GDP, FDI, PDI and PUB taken as endogenous variables Int and PI taken as exogenous variables.

Following the latest econometric practices (for example see Amassoma and Ogbuagu, 2014; Ajaz and Nazima, 2012; Lean and Tan, 2011; Saglam and Yalta, 2011; Ang, 2009; Tang et al., 2008; Ghani and Din, 2006; Badawi, 2003; Kim and Seo, 2003)., the system of interdependence among the three types of investment and GDP growth is captured by Vector Autoregressive (VAR) framework. The VAR models, pioneered by Sims (1980), is a commonly used system of equations for forecasting interrelated time series variables in a system as well as to analyze the dynamic impact of random disturbances on a set of variables. There are two reasons for preferring VAR model over conventional simultaneous equation models. Firstly, this model does not impose any restriction on the way in which one

\footnotetext{
${ }^{16}$ The roles of infrastructure (road density) (see Aysan et al., 2006) and cost of capital/investment (real interest rate) (Clausen, 2008; Aysan et al., 2006; Badawi, 2003) to explore investment behavior and explain the crowding-in and crowing out effects respectively, are exogenously defined/introduced.
} 
variable influences the others. Rather it endogenously treats the focused variables and captures the possible effects of contemporaneous shocks on these variables. Secondly, the extended VAR model i.e. Vector error correction model (VECM) considers both the long-run relationship and short-run dynamics. The model is analyzed with Johansen co-integration technique, while short-run dynamics are analyzed through Granger causality tests, impulse response functions (IRF), variance decomposition (VDC) analysis. VECM $^{17}$ is specified as follows.

$$
\begin{aligned}
& \Delta P D I_{t}=\alpha_{1}+\sum_{i=1}^{k} \alpha_{11 i} \Delta P D I_{t-i}+\sum_{i=1}^{k} \alpha_{12 i} \Delta P U B_{t-i}+\sum_{i=1}^{k} \alpha_{13 i} \Delta F D I_{t-i}+ \\
& \sum_{i=1}^{k} \alpha_{14 i} \Delta G D P_{t-i}+\beta_{1} P I_{t}+\gamma_{1} \operatorname{Int}_{t}+\delta_{1} E C M_{t-1}+\varepsilon_{1 t} \\
& \Delta P U B_{t}=\alpha_{2}+\sum_{i=1}^{k} \alpha_{21 i} \Delta P D I_{t-i}+\sum_{i=1}^{k} \alpha_{22 i} \Delta P U B_{t-i}+\sum_{i=1}^{k} \alpha_{23 i} \Delta F D I_{t-i}+ \\
& \sum_{i=1}^{k} \alpha_{24 i} \Delta G D P_{t-i}+\beta_{2} P I_{t}+\gamma_{2} \operatorname{Int}_{t}+\delta_{2} E C M_{t-1}+\varepsilon_{2 t} \\
& \Delta F D I_{t}=\alpha_{3}+\sum_{i=1}^{k} \alpha_{31 i} \Delta P D I_{t-i}+\sum_{i=1}^{k} \alpha_{32 i} \Delta P U B_{t-i}+\sum_{i=1}^{k} \alpha_{33 i} \Delta F D I_{t-i}+ \\
& \sum_{i=1}^{k} \alpha_{34 i} \Delta G D P_{t-i}+\beta_{3} P I_{t}+\gamma_{3} \operatorname{Int}_{t}+\delta_{3} E C M_{t-1}+\varepsilon_{3 t} \\
& \Delta G D P_{t}=\alpha_{4}+\sum_{i=1}^{k} \alpha_{41 i} \Delta P D I_{t-i}+\sum_{i=1}^{k} \alpha_{42 i} \Delta P U B_{t-i}+\sum_{i=1}^{k} \alpha_{43 i} \Delta F D I_{t-i}+ \\
& \sum_{i=1}^{k} \alpha_{44 i} \Delta G D P_{t-i}+\beta_{4} P I_{t}+\gamma_{4} \operatorname{Int}_{t}+\delta_{4} E C M_{t-1}+\varepsilon_{4 t}
\end{aligned}
$$

GDP and the investment variables are specified in terms of logs of real values in million rupees.

\subsection{Estimation Techniques}

First of all, stationarity properties of the variables are examined by Augmented Dickey Fuller (ADF) and Phillips Peron (PP) tests. When each variable is non-stationary at level and is stationary at first difference then there is possibility of co-integration i.e. long-run relationship. It is detected by using the Johansen's technique. $^{18}$

The chosen VECM model, estimated by maximum likelihood estimation (MLE) technique, provides more efficient results in the framework of cointegration and error correction. The VECM technique provides all the short-run and long-run dynamics in single step. The causality, impulse response and variance decomposition analyses are also carried out and accordingly explained below.

\footnotetext{
${ }^{17}$ In the small sample, the VECM provides more efficient results in the presence of exogenous variables and/or restrictions on the short-run equations or coefficients (see Pesaran et al., 2000). Ajaz and Nazima (2012) and Tang et al. (2008) have carried out similar type of analysis.

18 The Johansen-Juselius (JJ) approach is considered to be superior than residual based Engle and Granger's approach due to the fact that the former approach is capable of identifying more than one linear stationary combinations (i.e. cointegrating vectors) among variables (Asafu-Adjaye, 2000).
} 
The causality analysis is of great significance in the time series analysis. Both regression and correlation analyses do not imply causation. A single Granger causality test considers two null hypotheses that each of the two focused variables in the system do not cause each other. On the other hand, VDC or forecast error variance decomposition helps in interpreting the VAR model. The VDC explains the portion of variation in one variable that occurs as a result of shocks in itself and the portion that is explained by shocks in other variables of the system. Finally, IRF maps the time profile of changes in a variable due to changes in the innovations of current and other variables. It traces the effect of a one-time shock to one of the innovations on current and future values of the endogenous variables.

\section{Empirical Results and Discussion}

\subsection{Time Series Properties of Data}

Stationarity properties of underlying variables are examined by using ADF and PP tests. The ADF test may produce spurious results due to presence of structural breaks in the data whereas PP is non-parametric test and produces efficient results even in this case. The findings of two tests indicate that all the four (endogenous) variables are non-stationary and integrated of order one [I(1)]. Results of both the tests are provided in appendix.

Appropriate lag length is necessary before applying Johansen-Juselius (JJ) test of co-integration. Table 1 indicates that different criteria for lag length selection provide conflicting results. However, we select lag length two, which is supported by four of the five criteria.

Table 1: Lag Length Selection Criteria

\begin{tabular}{llllll}
\hline Lag & $\begin{array}{l}\text { Likelihood } \\
\text { Ratio }\end{array}$ & $\begin{array}{l}\text { Forecast } \\
\text { Prediction } \\
\text { Error }\end{array}$ & $\begin{array}{l}\text { Akaike } \\
\text { Information } \\
\text { Criterion }\end{array}$ & $\begin{array}{l}\text { Schwartz } \\
\text { Bayesian } \\
\text { Criterion }\end{array}$ & $\begin{array}{l}\text { Hannon } \\
\text { Quinn } \\
\text { Criterion }\end{array}$ \\
\hline 1 & NA & $1.87 \mathrm{e}-07$ & -4.143 & $-3.542^{*}$ & -3.912 \\
2 & $37.697^{*}$ & $1.48 \mathrm{e}-07^{*}$ & $-4.384^{*}$ & -3.183 & $-3.924^{*}$ \\
3 & 17.426 & $1.81 \mathrm{e}-07$ & -4.204 & -2.403 & -3.514 \\
4 & 23.422 & $1.84 \mathrm{e}-07$ & -4.239 & -1.838 & -3.319 \\
\hline
\end{tabular}

Note: The selected lag length is indicated by *. 


\subsection{Johansen Juselius (JJ) Co-integration Test}

The endogenous variables are found to be non-stationary at level but stationary at first difference i.e. I(1) series. The Johansen Juselius (JJ) cointegration test is, therefore, applied to explore the existence of co-integration among the variables. Results of the test are provided in table 2. The table shows that both Maximum Eigenvalue and Trace statistics indicate one co-integrating vector at $1 \%$ level of significance. Thus, there exists a single long-run relationship among the variables.

Table 2: JJ Co-integration Test and Normalized Equations

\begin{tabular}{lllllc}
\hline & $\mathbf{r}=\mathbf{0}$ & $\mathbf{r}=\mathbf{1}$ & $\mathbf{r}=\mathbf{2}$ & $\mathbf{r}=\mathbf{3}$ & C-I Vectors \\
\hline $\boldsymbol{\lambda}$ - Trace & 72.85 & 34.28 & 14.33 & 1.10 & 2 \\
& $(0.00)$ & $(0.01)$ & $(0.07)$ & $(0.29)$ & \\
$\lambda-\operatorname{Max}$ & 38.57 & 19.95 & 13.22 & 1.10 & 1 \\
& $(0.001)$ & $(0.07)$ & $(0.07)$ & $(0.29)$ & \\
\hline
\end{tabular}

The long-run relationship is captured through normalized co-integration equations. The results presented below reveal positive association among GDP and all the three types of investments. However, in the long run, all the three investments are crowding-out each other. The substitutability among the three types of investment is possibly due to competing nature of scarce capital and production resources (Elboiashi et al., 2009), lack of effective and efficient entrepreneurship as well as unfocused and non-targeted investments (Ajaz and Nazima, 2012). Moreover, the deficient infrastructure (accompanied with rising real interest rate) raises the cost of doing business hence crowd out the investment activities.

\section{Box 1: Normalized Equations Representing Long-Run Relationships}

Model 1: $\quad$ PDI $=6.80-0.60 \mathrm{PI}-0.58 \mathrm{FDI}+2.15 \mathrm{GDP}$

$$
(-3.62 * * *)(-5.52 * * *)(8.77 * * *)
$$

Model 2: $\quad$ PUB $=11.34-1.66$ PDI -0.97 FDI + 3.58 GDP

$$
(-2.06 * *) \quad(-5.37 * * *) \quad(6.05 * * *)
$$

Model 3: $\quad$ FDI $=11.58-1.70$ PDI -1.02 PI + 3.66 GDP

$$
(-2.07 * *) \quad(-3.54 * * *)(5.52 * * *)
$$

Model 4: $\quad$ GDP $=3.16+0.464$ PDI +0.278 PI + 0.272 FDI

$$
(3.26 * * *) \quad(3.96 * * *)\left(5.48^{* * *}\right)
$$

Note: The t-statistics significant at $1 \%$ and $5 \%$ levels are indicated by $* * *$ and $* *$ respectively. 


\subsection{Granger Causality Tests}

The detection of the co-integration among three types of investments and economic growth provides the signals of possible (at least unidirectional) Granger causation among the variables. Table 3 presents the Granger causality and ECM dynamics.

The results show that both foreign direct investment (FDI) and public investment (PUB) cause private domestic investment (PDI). FDI may substitute private investment through 'market stealing' and cutthroat competition or complement it through knowledge spillover and technology transfer (As pointed out in similar studies of Ang, 2009; Blomström et al., 2001; Wan, 2010). Similarly, public investment (PUB) may cause crowding-out/crowding-in effects respectively through rising interest rate (cost of capital) due to increase in public expenditures (fiscal deficit) or provision of infrastructure by enhancing the rate of return on investment (See Ang, 2009; Rossiter, 2002; Rama; 1993; Aschauer, 1989; Chibber and Wijnbergen, 1988; and Binter, 1977 for the similar results).

Table 3: Short and Long-run Causality

\begin{tabular}{|c|c|c|c|c|c|c|}
\hline \multirow{2}{*}{$\begin{array}{l}\text { Dependent } \\
\text { variable }\end{array}$} & \multicolumn{5}{|c|}{ VEC Granger Causality/Block Exogeneity Wald Tests } & \multirow{2}{*}{$\begin{array}{c}\text { ECM } \\
\text { adjustment } \\
\text { coefficient }\end{array}$} \\
\hline & $\begin{array}{l}\text { Lagged } \\
\text { PDI }\end{array}$ & $\begin{array}{l}\text { Lagged } \\
\text { PUB }\end{array}$ & $\begin{array}{l}\text { Lagged } \\
\text { FDI }\end{array}$ & $\begin{array}{l}\text { Lagged } \\
\text { GDP }\end{array}$ & $\begin{array}{c}\text { ALL } \\
\text { Variables }\end{array}$ & \\
\hline PDI & - & $\begin{array}{c}11.72 * * * \\
(0.002)\end{array}$ & $\begin{array}{c}6.12 * * \\
(0.04)\end{array}$ & $\begin{array}{c}1.36 \\
(0.51)\end{array}$ & $\begin{array}{c}21.13 * * * \\
(0.001)\end{array}$ & $\begin{array}{l}-0.04 * \\
(-1.67)\end{array}$ \\
\hline PUB & $\begin{array}{c}1.28 \\
(0.53)\end{array}$ & - & $\begin{array}{c}9.32 * * * \\
(0.009)\end{array}$ & $\begin{array}{l}0.895 \\
(0.64)\end{array}$ & $\begin{array}{c}12.46^{* *} \\
(0.05)\end{array}$ & $\begin{array}{l}-0.12 * * * \\
(-3.02)\end{array}$ \\
\hline FDI & $\begin{array}{c}2.46 \\
(0.29)\end{array}$ & $\begin{array}{c}3.19 \\
(0.20)\end{array}$ & - & $\begin{array}{l}12.93 * * * \\
(0.001)\end{array}$ & $\begin{array}{c}21.38 * * * \\
(0.001)\end{array}$ & $\begin{array}{l}-0.86 * * * \\
(-4.24)\end{array}$ \\
\hline GDP & $\begin{array}{l}6.24 * * \\
(0.04)\end{array}$ & $\begin{array}{c}3.79 \\
(0.15)\end{array}$ & $\begin{array}{c}1.01 \\
(0.60)\end{array}$ & - & $\begin{array}{l}11.70 * \\
(0.07)\end{array}$ & $\begin{array}{l}-0.005 \\
(-1.25)\end{array}$ \\
\hline
\end{tabular}

Note: In case of Wald test $\chi^{2}$ statistic is provided along with probabilities in parentheses. In case of ECM adjustment, the coefficients are provided along-with t-statistics in parenthesis. The statistics significant at $1 \%, 5 \%$ and $10 \%$ are indicated by $* * *, * *$ and $*$ respectively.

Public investment is found to be caused by FDI possibly through altering/increasing the economic activities and their contribution in government revenues (See Amassoma and Ogbuagu, 2014; Javed, 2011). However, public investment is not significantly caused by private investment, that is, there is no crowding-out or crowding-in effect of private investment on public investment. The results further show that GDP causes FDI. These results suggest that improved economic conditions and economic expansion/growth (rising demand in the 
economy) as well as infrastructural development attracts FDI (Ugwuegbe et al., 2014; Masuku and Dlamini, 2009; Välilä and Mehrotra, 2005; Hsiao and Shen, 2003).

Finally, GDP is found to be caused by FDI. This is the well know result that private investment stimulated economic activity through multiplier effect from demand side and long-run growth effect from supply side as productive/physical capacity grows as a result of investment. (See Ajaz and Nazima, 2012; Michaelides et al., 2005; and Badawi, 2003).

The tests of joint significance show that each of the four variables of the system is jointly caused by the rest of the three variables. This finding accentuates that the interdependence/interrelationship between the key macroeconomic variables in the system namely investment and output (Ajaz and Nazima, 2012; Lean and Tan, 2011; Tang et al., 2008; Kim and Seo, 2003; Badawi, 2003)

Further the results indicate that PDI is mainly determined by the levels of public investment and foreign direct investment in the short-run. Interestingly the PDI is causing GDP/economic growth while economic growth or rise in income level is attracting FDI in the short-run. Finally, the public investment (PUB) is not being determined by private domestic investment (PDI) and foreign direct investment (FDI) and economic (GDP) growth. It is possible that in the short-run public investment, the instrument of fiscal policy, is being exogenously determined by government decisions (Khan and Din, 2011).

The ECM term is negative and statistically significant each of the three categories of investment, indicating the presence of significant short-term dynamics for equilibrating adjustment following any shocks causing disequilibrium. It implies that all the variables cause each other to bring investments back toward the equilibrium. The speeds at which the error is correcting are $4.2 \%, 11.8 \%$ and $85 \%$ per year for private domestic investment (PDI), public investment (PUB) and foreign direct investment (FDI) respectively.

\subsection{Variance Decomposition (VDC) Analysis}

The VDC analysis is used to draw inferences about proportional variation in the dependent variable arising due to its own innovations as well as innovations of other variables (Enders, 1995). It also differentiates between the transitory and permanent shocks. The results of this technique mainly depend upon ordering of Cholesky factorization/decomposition (Lütkepohl, 1991). One of the major drawbacks of Cholesky decomposition is that it requires pre-specified assumptions regarding the contemporaneous no correlation among variables. This paper has 
applied various combinations/ordering and found the similar results. The finally chosen Cholesky ordering is PDI, PUB, FDI and GDP. The results of variance decomposition over a period of 20-years' time horizon are presented in Table 4.

According to the findings, variation in the PDI is mostly explained by its own shocks (59.59\% after five year and $44.09 \%$ after 20 years). However, the impact of its own innovations fades off with the passage of time. FDI contributes to PDI variation in a substantial way $(33.5 \%$ after five year and $48.32 \%$ after 20 years) and its contribution is rising over time. Contrarily GDP is explaining PDI the least.

In case of PUB, most of its variation is due to its own past shocks i.e. $81.5 \%$ after five year and $74.09 \%$ after 20 years while the shocks of other variables do not have considerable impact, hence supporting the finding of Granger causality.

Table 4: Variance Decomposition

\begin{tabular}{lllllllll}
\hline & \multicolumn{1}{c}{ Decomposition of PDI } & \multicolumn{5}{c}{ Decomposition of PUB } \\
\hline Periods & PDI & PUB & FDI & GDP & PDI & PUB & FDI & GDP \\
1 & 87.14 & 4.663 & 8.194 & 0.000 & 0.000 & 100.00 & 0.000 & 0.000 \\
5 & 59.59 & 4.824 & 33.50 & 2.084 & 1.834 & 81.526 & 14.709 & 1.929 \\
10 & 49.04 & 5.754 & 43.19 & 2.011 & 4.898 & 76.001 & 15.034 & 4.066 \\
15 & 45.80 & 5.823 & 46.53 & 1.840 & 5.798 & 74.732 & 15.028 & 4.441 \\
20 & 44.09 & 5.851 & 48.32 & 1.735 & 6.236 & 74.096 & 15.061 & 4.606 \\
\hline \multicolumn{4}{l}{ Decomposition of FDI } & \multicolumn{6}{c}{ Decomposition of GDP } \\
\hline Periods & PDI & PUB & FDI & GDP & PDI & PUB & FDI & GDP \\
1 & 0.000 & 0.219 & 99.780 & 0.000 & 13.998 & 0.009 & 2.201 & 83.791 \\
5 & 1.732 & 17.449 & 58.217 & 22.601 & 20.808 & 2.592 & 2.516 & 74.083 \\
10 & 1.499 & 22.770 & 53.521 & 22.208 & 22.243 & 1.773 & 2.938 & 73.045 \\
15 & 1.256 & 26.414 & 50.159 & 22.168 & 22.721 & 1.533 & 3.117 & 72.629 \\
20 & 1.084 & 29.065 & 47.670 & 22.180 & 22.963 & 1.413 & 3.208 & 72.414 \\
\hline
\end{tabular}

In the time horizon of 20 years, the movements in FDI are fairly explained by its own past innovations i.e. $47.67 \%$. Only $1.08 \%$ of variation in FDI is due to PDI. The other major contributing factors to FDI are PUB and GDP explaining the $29.06 \%$ and $22.18 \%$ of variation respectively. Finally, PDI plays an important role in variation in GDP or economic growth i.e. $22.96 \%$. On the other hand, role of FDI and PUB is very low i.e. $3.2 \%$ and $1.41 \%$ respectively. GDP is strongly influenced by its own past innovations i.e. $72.41 \%$. 


\subsection{Impulse Response Functions (IRF)}

Impulse response functions (IRFs) represent the responsiveness of (endogenous) variables due to changes in the innovations (one-time shock to one of the innovations) of all variables of the given system in current and future periods. An IRF maps the time profile of a one-time shock on the values of a variable (Brooks, 2008). Many studies have utilized the IRF technique to analyze the interrelationship (substitutability/complementarity effect) among the variables (Tang et al., 2008; Gan et al., 2006; Kim and Seo, 2003; Borensztein et al., 1998;). The maps of IRF derived from our data are presented in Figure 1.

The figure shows that PDI is positively influenced by PUB but strongly crowded out by FDI. The impact of PDI on FDI is minimal. FDI substitutes PDI because both local and foreign firm compete for scarce resources, as foreign firms are advanced in technology and more efficient, so they become the winners (Lean and Tan, 2011). The immediate impact of innovations in public investment (PUB) on itself is weak but it becomes strong after a lag of three years after which remains stable. The shock in foreign direct investment (FDI) has strong negative impact on PUB within one-year lag. The figure shows that FDI substitutes PUB more than the PDI. On the other hand, FDI is largely influenced by PUB hence they largely crowd out each other.

Finally, Gross domestic product (GDP) effects all three investments positively whereas its impact is largest in case of FDI showing that better economic conditions attract FDI. The results support the accelerator principle as well as confirm the Wagner's law (see Välilä and Mehrotra, 2005; Sturm, 2001). ${ }^{19}$ Moreover, the positive nexus between GDP and public investment (PUB) may be attributed to pro-cyclical behavior of public investment (Välilä \& Mehrotra, 2005). Importantly, conducive economic environment and favorable investment climate are the key factors to enhance investment activity, especially in the developing economies like Pakistan (Saglam and Yalta, 2011; Ndikumana and Verick, 2008).

\section{Conclusion and Policy Implications}

This study empirically analyzes the dynamic relationship among three types of investments namely private domestic investment, foreign direct investment and public investment to explore the presence of crowding-in/out effect. The vector error correction model (VECM) technique is employed to explore long-run stable relationship and short-run dynamics over the period of 1960 to 2015.

\footnotetext{
${ }^{19}$ It implies to increase in the infrastructure demand associated with rise in output/income level.
} 
Figure 1: Impulse Response Functions (IRFs) based on Cholesky Decomposition

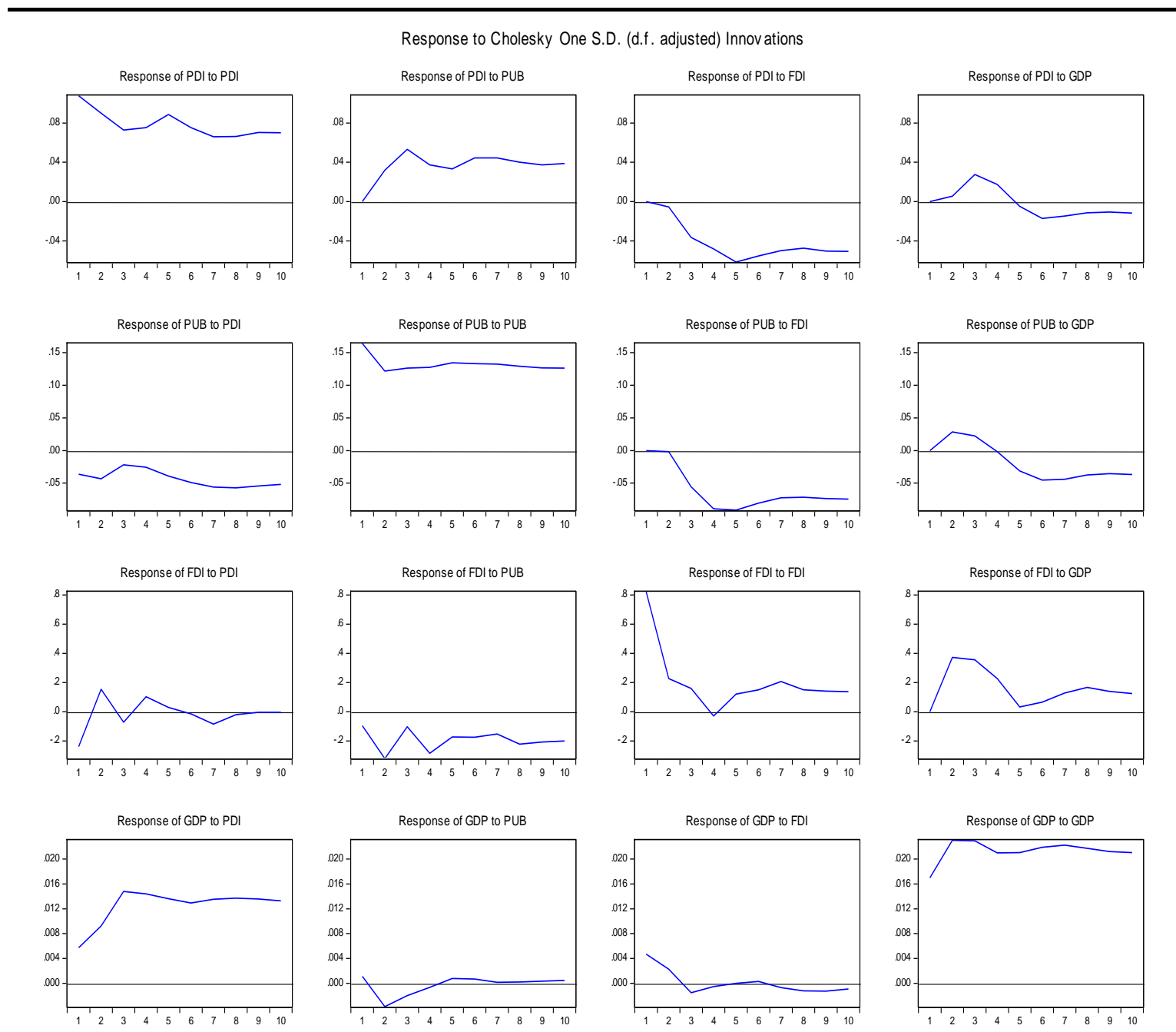

The long-run relationships are explored using the Johansen-Juselius (JJ) cointegration technique. In the long-run the three categories of investment are found to crowd-out/substitute each other. The substitutability or competing behavior among the investments may be due to deficiency of requisite (physical) infrastructure, high cost of capital/investment, inefficient financial market and competition in acquisition of limited available (domestic) resources.

The plausible reason behind crowding-out effect of public investment on private investment may be due to the financing of public investment expenditure through 
domestic and foreign borrowing and possible hike in interest rate. Government also collects the investable funds, increasing the tax rate and or borrowing, which may impact the level of private investment (Ajaz and Nazima, 2012). On the other hand, all three investments are positively contributing to economic growth.

Though the foreign direct and public investments are positively contributing to GDP, yet the major contribution is made by private domestic investment. The probable reason may be the misallocation of resources towards unproductive uses made by public investment (Devarajan, et al., 1996). Similarly, the reasons of relatively low impact of foreign direct investment on economic growth are that physical infrastructure and requisite capital are below the threshold level that may not be enough to grasp the fruits of foreign (direct) investment in advanced technological form.

The proposed policy guidelines for public investment in the wake of crowding-out effect of public investment on private investment are that the role of public investment may be mostly confined to productive sectors and non-competing enterprises with private sector. As private domestic investment turns out to be the main engine of growth and public investment does not complement with private (domestic) investment, there is no justification of undertaking public investment at the cost of private (domestic) investment and all efforts are to be diverted towards promotion of private domestic investment.

Private sector could also be engaged in infrastructure development projects through public private partnership (PPP) and build-operate-transfer (BOT) arrangements. Foreign direct investment (FDI is also not complementing with private domestic investment. This means that within the given economic environment and physical infrastructure, there is no strong case for Pakistan to rely on foreign investment for growth either in terms of direct impact of foreign direct investment on GDP growth or through possible complementary relationship of foreign (direct) investment with domestic investment (private/public).

In a nutshell, the main conclusion is that as far as investment as a source of economic growth is concerned, it is the private domestic investment that needs to be focused. The public sector may focus on provision of better physical infrastructure i.e. improvement of road network to enlarge the market access and reduce the cost of production as well as transaction costs. Further efforts need to be made to enhance the efficiency and development of financial and banking sector to reduce the cost of capital and ease the liquidity constraint to stimulates the investment activity in the economy. 


\section{References}

Acar, S., Eris, B., \& Tekce, M. (2012). The Effect of Foreign Direct Investment on Domestic Investment: Evidence from MENA Countries. European Trade Study Group (ETSG) 14th Annual Conference, Leuven, Belgium, 13-15

Adams, S. (2009). Foreign Direct Investment, Domestic Investment, and Economic Growth in Sub-Saharan Africa. Journal of Policy Modelling, 31(6), 939949.

Agosin, M. R., \& Machado, R. (2005). Foreign Investment in Developing Countries: Does It Crowd in Domestic Investment? Oxford Development Studies, 33(2), 149-162.

Agosin, M., \& Mayer, R. (2000). Foreign Direct Investment: Does It Crowd in Domestic Investment. United Nations Conference on Trade and Development Working Paper No. 146.

Ahmad, I., \& Qayyum, A. (2009). Role of Public Expenditures and Macroeconomic Uncertainty in Determining Private Investment in Large Scale Manufacturing Sector in Pakistan. International Research Journal of Finance and Economics 26, 34-40.

Ahmad, I., Qayyum, A., \& Salam, A. (2008). Dynamic Modeling of Private Investment in Agricultural Sector of Pakistan [with Comments]. The Pakistan Development Review, 47(4), 517-530.

Ajaz, M. B., \& Nazima, E. (2012). Public-Private Investment and Economic Growth in Pakistan: An Empirical Analysis. The Pakistan Development Review 51(4) 61-78.

Alfaro, L., Charlton, A., \& Kanczuk, F. (2007). Firm-Size Distribution and CrossCountry Income Differences. National Bureau of Economic Research (NBER), 14060.

Ali, S. M., Hasan, R., \& Iqbal, A. (2015). Dynamic Linkages between Foreign Direct Investment, Public Investment and Private Domestic Investment: Evidence from Pakistan? Pakistan Business Review, 789-807.

Amassoma, D., \& Ogbuagu, M. I. (2014). FDI, Private Investment and Public Investment in Nigeria: An Unravelled Dynamic Relation. Journal of Business and Economic Policy, 1(2), 29-38.

Ang, J. B. (2009). Do Public Investment and FDI Crowd in or Crowd out Private Domestic Investment in Malaysia? Applied Economics, 41(7), 913-919. 
Apergis, N., Katrakilidis, C. P., \& Tabakis, N. M. (2006). Dynamic Linkages between FDI Inflows and Domestic Investment: A Panel Co-Integration Approach. Atlantic Economic Journal, 34(4), 385-394.

Asafu-Adjaye, J. (2000). The Effects of Foreign Direct Investment on Indonesian Economic Growth, 1970-1996. Economic Analysis and Policy, 30(1), 4962.

Aschauer, D. A. (1989). Does Public Capital Crowd Out Private Capital? Journal of Monetary Economics, 24, 171-88.

Atukeren, E. (2005). Economic and Institutional Determinants of the Crowding-in Effects of Public Investment and Developing Countries. Swiss Institute for Business Cycle Research (KOF) and Swiss Federal Institute of Technology Zurich (ETH).

Aysan, A. F., Nabli, M. K., \& VÉganzon Ès-varoudakis, M. A. (2006). Governance Institutions and Private Investment: An Application to the Middle East and North Africa. The Developing Economies, 45(3), 339-377.

Azam, M., \& Lukman, L. (2010). Determinants of Foreign Direct Investment in India, Indonesia and Pakistan: A Quantitative Approach. Journal of Managerial Sciences, 4(1).

Badawi, A. (2003). Private Capital Formation and Public Investment in Sudan: Testing the Substitutability and Complementarity Hypotheses in a Growth Framework. Journal of International Development, 15(6), 783-799.

Balassa, B. (1988). The Lessons of East Asian development: An Overview. Economic Development and Cultural Change, 36(3), 273-S290.

Balcerzak, A. P., \& Rogalska, E. (2014). Crowding-out and Crowding-in within Keynesian Framework. Do We Need any New Empirical Research Concerning Them? Economics \& Sociology, 7(2), 80.

Barro, R. J. (1990). The Stock Market and Investment. The Review of Financial Studies, 3(1), 115-131.

Binter, W.H. (1977). Crowding-Out and the Effectiveness of Fiscal Policy. Journal of Public Economics, 7.

Blanchard, O. J., \& Fischer, S. (1989). Lectures on Macroeconomics. MIT Press. 
Bleaney, M., \& Greenaway, D. (1993). Adjustment to External Imbalance and Investment Slumps in Developing Countries. European Economic Review, 37(2-3), 577-585.

Blejer, M. I., \& Khan, M. (1984). Government Policy and Private Investment in Developing Countries, IMF Staff Papers, 31(2), 379-403.

Blomström, M., Kokko, A., \& Globerman, S. (2001). The determinants of host country spillovers from foreign direct investment: a review and synthesis of the literature. In Inward Investment Technological Change and Growth (pp. 34-65). Palgrave Macmillan, London.

Borensztein, E., De Gregorio, J., \& Lee, J. W. (1998). How Does Foreign Direct Investment Affect Economic Growth? Journal of international Economics, 45(1), 115-135.

Bosworth, B. P., Collins, S. M., \& Reinhart, C. M. (1999). Capital flows to Developing Economies: Implications for Saving and Investment. Brookings Papers on Economic Activity, 1999(1), 143-180.

Brooks, C. (2008). Introductory Econometrics for Finance, Second Edition. Cambridge University Press.

Cardoso, E. (1993). Private Investment in Latin America. Economic Development and Cultural Change, 833-848.

Carkovic, M. And Levine, R. (2005) Does Foreign Direct Investment Accelerate Economic Growth? In in The Impact of Foreign Direct Investment on Development: New Measurements, New Outcomes, New Policy Approaches.

Carlson, K. M., \& Spencer, R. W. (1975). Crowding-out and its Critics. Federal Reserve Bank of St. Louis Review.

Chaudhry, N. I., Mehmood, A., \& Mehmood, M. S. (2013). Empirical Relationship between Foreign Direct Investment and Economic Growth: An ARDL Cointegration Approach for China. China Finance Review International, 3(1), 26-41.

Chibber, A., \& Van Wijnbergen, S. (1988). Public Policy and Private Investment in Turkey, Working Paper No. 120, World Bank.

Clausen, B. (2008). Real Effective Exchange Rate Uncertainty, Threshold Effects, and Aggregate Investment: Evidence from Latin American Countries. IWP Discussion Paper. 
De Backer, K., \& Sleuwaegen, L. (2003). Does Foreign Direct Investment Crowd Out Domestic Entrepreneurship? Review of Industrial Organization, 22(1), 67-84.

De Soysa, I., \& Oneal, J. R. (1999). Boon or bane? Reassessing the Productivity of Foreign Direct Investment. American Sociological Review, 766-782.

Devarajan, S., Swaroop, V., \& Zou, H. F. (1996). The Composition of Public Expenditure and Economic Growth. Journal of Monetary Economics, 37(2), 313-344.

Elboiashi, H., Noorbakhsh, F., Paloni, A., \& Azemar, C. (2009). The Casual Relationships between Foreign Direct Investment, Domestic Investment and Economic Growth in North African Non-oil Producing Countries: Empirical Evidence from Co-integration Analysis. Advances in Management, 2, 19-25.

Enders, W. (1995). Applied Econometric Time Series. John Wiley \& Sons.

Erden, L., \& Holcombe, R. G. (2005). The Effects of Public Investment on Private Investment in Developing Economies. Public Finance Review, 33(5), 575602.

Eregha, P. B. (2012). The Dynamic Linkages between Foreign Direct Investment and Domestic Investment in ECOWAS Countries: A Panel Co-integration Analysis. African Development Review, 24(3), 208-220.

Ermisch, J. F., \& Huff, W. G. (1999). Hypergrowth in an East Asian NIC: Public Policy and Capital Accumulation in Singapore. World Development, 27(1), 21-38.

Ford, J. L., Somnath, S., \& Hongxu, W. (2010). A Simultaneous Equation Model of Economic Growth, FDI and Government Policy in China. Department of Economics Discussion Paper, 10-25, University of Birmingham.

Friedman, B. M. (1978). Crowding Our or Crowding In? The Economic Consequences of Financing Government Deficits, Brookings Papers on Economic Activity, 3, 655-685.

Fry, M. J. (1997). How Foreign Direct Investment in Pacific Asia Improves the Current Account. Journal of Asian Economics, 7(3), 459-486.

Gan, C., Lee, M., Yong, H. H. A., \& Zhang, J. (2006). Macroeconomic Variables and Stock Market Interactions: New Zealand Evidence. Investment Management and Financial Innovations, 3(4), 89-101. 
Ghani, E., \& Din, M. (2006). The Impact of Public Investment on Economic Growth in Pakistan. The Pakistan Development Review 45(1), 87-98.

Gjini, A., \& Kukeli, A. (2012). Crowding-out Effect of Public Investment on Private Investment: An Empirical Investigation. Journal of Business \& Economics Research (JBER), 10(5), 269-276.

Greene, J., \& Villanueva, D. (1991). Private Investment in Developing Countries: An Empirical Analysis. IMF Staff Papers, International Monetary Fund, 38(1), 33-58.

Hanif, A., \& Jalaluddin, S. (2013). FDI and Domestic Investment in Malaysia. International Proceedings of Economics Development \& Research, 76, 15-20.

Hsiao, C., \& Shen, Y. (2003). Foreign Direct Investment and Economic Growth: The Importance of Institutions and Urbanization. Economic Development \& Cultural Change, 51(4), 883-896. The University of Chicago.

Jansen, K. (1995). The Macroeconomic Effects of Direct Foreign Investment: The Case of Thailand. World Development, 23(2), 193-210.

Javed, S. M. (2011). Uncertainty, Foreign Direct Investment and Economic Growth: Evidence from Developing Asia, Ph.D. Thesis, International Islamic University, Islamabad.

Jin, J. C., \& Yu, E. S. H. (1996). Export-led Growth and the US Economy: Another Look. Applied Economics Letters, 3(5), 341-44.

Kamaly, A. (2014). Does FDI Crowd in or out Domestic Investment? New Evidence from Emerging Economies. Modern Economy, 5(04), 391.

Khan, M. A., \& Din, M. (2011). A Dynamic Macroeconometric Model of Pakistan's Economy. PIDE Working Papers, 2011:69.

Kim, D. D. K., \& Seo, J. S. (2003). Does FDI Inflow Crowd out Domestic Investment in Korea? Journal of Economic Studies, 30(6), 605-622.

Lean, H. H., \& Tan, B. W. (2011). Linkages between Foreign Direct Investment, Domestic Investment and Economic Growth in Malaysia. Journal of Economic Cooperation \& Development, 32(4), 75.

Lee, K. S. (1991). Private Alternatives to Public Sector Investment Deficiencies: The Case of Nigerian Manufacturing, in Chibber. Analytics of Economic Reforms in Sub-Saharan Africa, World Bank, Washington D. C. 
Lipsey, R. E. (2000). Affiliates of US and Japanese Multinationals in East Asian Production and Trade. In the Role of Foreign Direct Investment in East Asian Economic Development, NBER-EASE, 9, 147-189.

Looney, R. E. (1997). Infrastructure and Private Sector Investment in Pakistan. Journal of Asian Economics, 8(3), 393-420.

Lütkepohl, H. (1991). Periodic VAR Processes and Intervention Models. In Introduction to Multiple Time Series Analysis, 391-414. Springer, Berlin, Heidelberg.

Masuku, M. B., \& Dlamini, T. S. (2009). Determinants of Foreign Direct Investment Inflows in Swaziland. Journal of Development and Agricultural Economics, 1(5), 177-184.

Michaelides, P. G., Athena, R., \& John, M. (2005). The Determinants of Investment Activity in Greece (1960-'1999). Journal of Transport and Shipping, $f$. Aegean Working Papers (3), 23-45.

Naqvi, N. H. (2002). Crowding-in or Crowding-out? Modelling the Relationship between Public and Private Fixed Capital Formation using Co-Integration Analysis: The Case of Pakistan 1964-2000. The Pakistan Development Review, 255-275.

Nasser, O. M. Al. (2007). The Determinants of the U.S. Foreign Direct Investment: Does the Region Matter? Global Economic Review, 36(1), 37-51.

Naz, A., Ali, S., \& Yaqub, R. M. S. (2015). Impact of FDI and Trade Balance on Economic Growth during 1990-2014, A Case Study of Pakistan. Historical Research Letter, 25, 25-29

Ndikumana, L., \& Verick, S. (2008). The Linkages between FDI and Domestic Investment: Unravelling the Developmental Impact of Foreign Investment in Sub-Saharan Africa. Development Policy Review, 26(6), 713-726.

Noorzoy, M. S. (1979). Flows of Direct Investment and Their Effects on Investment in Canada. Economics Letters, 2(3), 257-261.

Noorzoy, M. S. (1980). Flows of Direct Investment and Their Effects on US Domestic Investment. Economics Letters, 5(4), 311-317.

Olusanya, S. O. (2013). Impact of Foreign Direct Investment Inflow on Economic Growth in a Pre and Post Deregulated Nigeria Economy. A Granger Causality Test (1970-2010). European Scientific Journal (ESJ), 9(25). 
Oshikoya, T. W. (1994). Macroeconomic Determinants of Domestic Private Investment in Africa: An Empirical Analysis. Economic Development and Cultural Change, 42(3), 573-596.

Pesaran, M. H., Shin, Y., \& Smith, R. J. (2000). Structural Analysis of Vector Error Correction Models with Exogenous I(1) Variables. Journal of Econometrics, 97(2), 293-343.

Qi, L. (2007). The Relationship between Growth, Total Investment and Inward FDI: Evidence from Time Series Data. International Review of Applied Economics, 21(1), 119-133.

Rama, M. (1993). Empirical Investment Equations for Developing Countries. Striving for Growth after Adjustment: The Role of Capital Formation, 107143.

Ramirez, M. D. (1994). Public and Private Investment in Mexico, 1950-90: An Empirical Analysis. Southern Economic Journal, 1-17.

Rashid, A. (2006). Public-Private Investment Linkage in Pakistan: A Multivariate Co-integration Analysis. South Asia Economic Journal, 7(2), 219-230.

Rossiter, R. (2002). Structural Co-integration Analysis of Private and Public Investment. International Journal of Business and Economics, 1(1), 59.

Saglam, B. B., \& Yalta, A. Y. (2011). Dynamic Linkages among Foreign Direct Investment, Public Investment and Private Investment: Evidence from Turkey. Applied Econometrics and International Development, 11(2), 7182.

Sakr, M. K. (1993). Determinants of Private Investment in Pakistan. International Monetary Fund (IMF).

Shafik, N. (1992). Modeling Private Investment in Egypt. Journal of Development Economics, 39(2), 263-277.

Sims, C. A. (1980). Macroeconomics and Reality. Econometrica: Journal of the Econometric Society: 1-48.

Sturm, J. E. (2001). Determinants of Public Capital Spending in Less-Developed Countries. University of Groningen. Available at: https://www.rug.nl/research/portal/files/3086743/200107. pdf

Sun, H. (1998). Macroeconomic Impact of Direct Foreign Investment in China: 1979-96. The World Economy, 21(5), 675-694. 
Sunny, D., \& Sawant, A. (2012). Crowding-in and Crowding-out Impacts of FDI on Domestic Investment: An Indo-China Analysis. In APEA Annual International Conference 28-29 June, Singapore.

Tang, S., Selvanathan, E. A., \& Selvanathan, S. (2008). Foreign Direct Investment, Domestic Investment and Economic Growth in China: A Time Series Analysis. The World Economy, 31(10), 1292-1309.

Titarenko, D. (2006). The Influence of Foreign Direct Investment on Domestic Investment Processes in Latvia, Transport and Telecommunication Institute, MPRA Papers, 7(1), 76. Available at: https://mpra.ub.unimuenchen.de/18192/

Ugwuegbe, S., Ugochukwu, M., Nwanneka, J. \& Onyeanu, E. (2014). The Impact of Foreign Direct Investment on Capital Formation in Nigeria: A Cointegration Approach. International Journal of Economics, Finance and Management Sciences, 2(2), 188-196.

Välilä, T. and Mehrotra, M. (2005). Evolution and Determinants of Public Investment in Europe. Economic and Financial Report 2005/01. European Investment Bank.

Van Loo, F. (1977). The Effect of Foreign Direct Investment on Investment in Canada. The Review of Economics and Statistics, 474-481.

Voss, G. M. (2002). Public and Private Investment in the United States and Canada. Economic Modelling, 19(4), 641-664.

Wai, U. T., \& Wong, C. H. (1982). Determinants of Private Investment in Developing Countries. The Journal of Development Studies, 19(1), 19-36.

Wan, X. (2010). A Literature Review on the Relationship between Foreign Direct Investment and Economic Growth. International Business Research, 3(1), $52-56$. 
Appendix: Unit Root Tests

\begin{tabular}{|c|c|c|c|c|}
\hline & $\begin{array}{l}\text { Augmented } \\
\text { Dickey Fuller } \\
\text { Test }\end{array}$ & $\begin{array}{l}\text { Phillips } \\
\text { Perron Test }\end{array}$ & $\begin{array}{l}\text { Augmented } \\
\text { Dickey Fuller } \\
\text { Test }\end{array}$ & $\begin{array}{l}\text { Phillips } \\
\text { Perron Test }\end{array}$ \\
\hline Variables & Level & & First Difference & \\
\hline GDP & $\begin{array}{l}-1.228 \\
(0.894)\end{array}$ & $\begin{array}{l}-1.313 \\
(0.874)\end{array}$ & $\begin{array}{l}-5.762 * * * \\
(0.000)\end{array}$ & $\begin{array}{l}-5.684 * * * \\
(0.000)\end{array}$ \\
\hline PDI & $\begin{array}{l}-2.04 \\
(0.266)\end{array}$ & $\begin{array}{l}-2.05 \\
(0.265)\end{array}$ & $\begin{array}{l}-8.92 * * * \\
(0.000)\end{array}$ & $\begin{array}{l}-10.99 * * * \\
(0.00)\end{array}$ \\
\hline PUB & $\begin{array}{l}-2.55 \\
(0.1075)\end{array}$ & $\begin{array}{l}-2.559 \\
(0.107)\end{array}$ & $\begin{array}{l}-7.338 * * * \\
(0.000)\end{array}$ & $\begin{array}{l}-7.337 * * * \\
(0.000)\end{array}$ \\
\hline FDI & $\begin{array}{l}-0.35 \\
(0.908)\end{array}$ & $\begin{array}{l}-2.674 \\
(0.084)\end{array}$ & $\begin{array}{l}-4.435^{* * * *} \\
(0.000)\end{array}$ & $\begin{array}{l}-20.37 * * * \\
(0.000)\end{array}$ \\
\hline Int & $\begin{array}{l}-4.383 * * * \\
(0.000)\end{array}$ & $\begin{array}{l}-4.39 * * * \\
(0.000)\end{array}$ & & \\
\hline PI & $\begin{array}{l}-2.19 * * \\
(0.028)\end{array}$ & $\begin{array}{l}-1.26 \\
(0.187)\end{array}$ & & $\begin{array}{l}-3.75 * * * \\
(0.000)\end{array}$ \\
\hline
\end{tabular}

Note: Specification for GDP is constant and trend. Specification for PI is 'no constant' as it is detrended variable. P-values are provided in the brackets. The coefficients significant at $1 \%$ and $5 \%$ are indicated by $* * *$ and $* *$. 